\title{
Foreign Languages: The Key Factor in Employability
}

\author{
FITNETE MARTINAJ \\ International School for Social and Business Studies, Slovenia \\ fitnetemartinaj@hotmail.com
}

The globalization of knowledge, and of higher education itself, is contributing to an increasing use of foreign languages. Nowadays, labour markets worldwide demand employees and graduates who possess foreign language proficiency and good communication skills. The aim of this article is to show that possessing foreign language skills offers graduates and employees the opportunity of a better job, career success and promotion. This study investigates the role of foreign language skills in the employability and success of Kosovo citizens. In addition, an international review of the effects of language skills on effective communication is provided in order to make a national and international comparison. Our findings support the hypothesis that foreign languages constitute a good amount of knowledge management which generates success for both graduates and employees. We will try to prove this hypothesis through a relevant literature review and others' research. This article's objective is to explore the benefits of learning foreign languages. The results show that the use of foreign languages is crucial for employment, career success, knowledge sharing and cross-cultural communication.

Key words: foreign language skills, employability, communication, career success

(c) BY-SA https://doi.org/10.26493/1854-4231.15.161-178

\section{Introduction}

Language skills, communication skills, adaptability skills, and critical thinking skills are some of the key attributes that graduates should have when they intend to enter labour market and when professionals are required to work with advanced technologies. The research carried out by the uk Subject Centre for Languages (Gallagher-Brett 2004) identified more than 700 reasons to study languages, which were arranged into the following categories: citizenship; communication; economic; social and political dimensions; democracy; diversity; employability; environmental sustainability; equal opportunities; globalization; identity; intercultural competence; international 
dimension and foreign policy; key skills; language awareness; mobility/travel; multilingualism; personal and social development of the individual and values. The 'Languages for Jobs' report (European Commission 2011a) shows that the demand for foreign language skills in the European labour market is steadily rising and also bound to increase in the short to medium-term future. The socio-economic and cultural position of a specific nation is reflected through language. Employers are constantly in need of employees with strong communication skills covering a wide range of verbal and written communication (European Commission 2011a). According to the ELAN study (CILT 2006) on the effects on the European economy of shortages of foreign language skills in enterprise, a significant amount of business is being lost in the $\mathrm{EU}$ due to a lack of language skills. Studies show that education systems have to respond better to pupils' learning and professional needs and work more closely with employers, chambers of commerce and other stakeholders, linking language teaching to the creation of career paths. Using data from the European Commission (2011a), the analyses show that English, German and French are the most widely learnt foreign languages in Europe. Adults who know one or more foreign languages are more likely to be employed than those who do not know any foreign language. As stated above, there are many reasons to study languages. However, this study is limited to the investigation of only some of them, including employment, communication, intercultural competence and career success.

\section{Language and Cultural Skills Dimension on Employability of Kosovo Citizens}

Youth unemployment is a huge problem in Kosovo. The country's current youth unemployment is as high as $57.7 \%$ (Rrumbullaku 2019). The results for individual countries show that in 17 out of 24 European Member States, knowing foreign languages and/or being proficient in at least one is positively related with employment status. Given that Kosovo people live and operate in a common territory with one or more communities that speak a different language, the relationship they create with each other's language reflects the esteem they have for the other's culture and traditions in general. Kosovo, being a European country, has had a unique past compared to other countries because it has been under an international administration for many years. This administration's language of operation is English and it is amazing the amount of effect that this administration has had upon Kosovo institutions. During the 
United Nations Mission in Kosovo (UNMIK) period, English has been the most important language (Polloshka 2018). UNMIK was responsible for the reconstruction and development of education system in Kosovo and its authority was based on three main areas: physical reconstruction; legal reconstruction; and academic reconstruction (Pichl 1999). According to the World Bank report (2012), the quality of education in Kosovo is lower than in EU countries and this has created difficulties for new employees in the labour market, and reflected negatively on the economic growth of the country. English and other languages spoken inside Kosovo provide grounds for a multicultural business environment (Multilingualism features in Kosovo are provided in table 1). Albanian is the official language, along with Serbian. Other languages including Turkish, Romani, and Bosnian are also spoken in Kosovo. English is widely spoken, especially by the young. English is also taught at schools starting from primary education while German is widely spoken in general society (http://www.beinkosovo.com). According to the Kosovo Agency of Statistics (2013), the role of foreign language skills in the intercultural and international business communication of Kosovo people is further reinforced by two important factors: (1) overall, the most important target countries of Kosovo's business companies are different language-speaking countries, and (2) the Kosovo diaspora resides in some of the most highly industrialized Western economies, where they are able to accumulate substantial capital, gain advanced skills and develop effective networks. Thus, the skill 'fluent in foreign languages' is statistically significant in Kosovo, suggesting that individuals are socialized and well networked. To date, there has been no systematic attempt to measure foreign language skills directly in Kosovo and analysis has been limited to inexact approximations of skills such as education levels, years of schooling, or occupational categories. Workers with more skills improve their own productivity as well as that of other workers, increase capital productivity, and facilitate innovation and the adoption of new technology. Better skills in foreign languages, marketing, sales, and design, as well as computer skills are important for Kosovo companies to compete in markets. To address these needs, the Vocational and Education Training (VET) system needs to be better aligned with the skill demands in these areas. While commerce and services are the two sectors that accounted for most of the new jobs over the past decade, the sectorial profile of VE T students is heavily skewed toward business/law, as well as medicine and computer science, whereas the share of VET students in the services skill sector (based on Eurostat

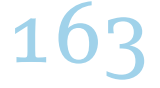


1 Kosovo provide grounds for a multicultural business environment.

2 Kosovo people live and operate in a common territory with one or more communities that speak a different language.

3 English is the most important foreign language.

4 Albanian is the official language, along with Serbian.

5 Other local languages include Turkish, Romani and Bosnian.

6 English is widely spoken, especially by the young.

7 German is widely spoken in general society.

categorization) is very low in relation to the share of jobs created in services (Skills 2020 Kosovo 2014).

The Kosovo Jobs Diagnostic Report (Cojocaru 2017) shows that English and computer skills are deficient in Kosovo institutions. Employers were asked to evaluate, for a set of skills, whether there were differences between what is required for the job and the current level of this skill in a typical worker. On average, less than five per cent of firms thought there were differences between the skills of typical Type A workers and job requirements. For Type B workers the gap is somewhat wider, but still less than 10 percent for most skills. Insufficient skills are most common with respect to knowledge of foreign languages (especially English), as well as insufficient computer skills (basic word processing skills for Type B; presentations and/or other advanced purposes such as creating and managing databases, or using specialized computer programs for Type A). Skills gap analysis (Hapçiu and Osmani 2018) is a trending topic among businesses and policymakers, and it refers to the fact that private sector employers encounter significant difficulties in finding skilled and qualified labour for particular operations within their companies. At first sight, this concern seems paradoxical, not least because the unemployment rate in the country is at staggering levels, whereas the number of people enrolling in higher education institutions is double of that of the European Union. In normal circumstances, such figures on higher education enrolment should be an indicator of the talent and skill abundance in the labour market, an element that would make domestic companies much more competitive in regional and broader terms. At present, the country has structural challenges in terms of being able to prepare a skilled labour force in line with needs and demands. This inability of education institutions to build a workforce in line with what the labour market needs has been elaborated in detail at Skills Gap Analysis, which focused on manufacturing, trade and professional services (Hapçiu and Osmani 
2018). Moreover, skills explain most of country's variations in longterm growth rates, and even small improvements in skills could raise growth rates significantly. Increasing the level and relevance of skills of the workforce is consequently a central focus of the Employment and Social Welfare Strategy 2018-2022 of the Government of Kosovo (The World Bank 2019).

\section{Language Effects on the Employment of Graduates}

The employment of graduates is becoming an increasingly prominent economic and social problem and has attracted extensive attention from researchers, who suggest that entrepreneurship education has a positive influence on entrepreneurial behaviour and employment performance (Martin, McNally, and Kay 2013). Kosovo has the youngest population in Europe with a median age of 29.5 years, and youth are the country's great asset. The last decade has seen a significant increase in the number of young people attending university. Finding a good job upon graduation is an important milestone for young people, but the transition to employment in Kosovo often comes with many challenges. Finding solutions to improve educational and employment opportunities for young people is essential to Kosovo's development (The World Bank 2012). The ten basic competences pointed out by the European Commission wherein foreign language skills is specified, remain at a poor level in Kosovo and this requires a greater focus on improving school curricula, starting from earlier grades (Skills 2020 Kosovo 2014). Regardless of enormous efforts by Kosovo institutions and international donors to create employment policies and appropriate strategies for the labour market through education and vocational training, Kosovo still continues to have a high rate of unemployment (Kita 2008). According to the Ministry of Labour and Social Welfare (2010), the main objective of the ministry in Kosovo is to adopt a sectorial strategy and action plan for increasing of employment and strengthening vocational training, in accordance with the labour market demands. Leitch, Hazlett, and Pittaway (2012) place the role of entrepreneurial education in broader contexts by considering entrepreneurship as a way of thinking and behaving, suggesting that the benefits of building the national entrepreneurial culture is not limited only to the creation of new ventures, but rather to preparing students for the labour market. The perceived capabilities for entrepreneurship may be seen as high self-efficacy among the Kosovan students which indeed indicates 'the strong personal belief in skills and abilities to initiate a task and lead it to success' (Bandura 1997). As Markman, Balkin, and 
Baron (2002) note, the perceptions of self-efficacy are very critical in entrepreneurship, because self-efficacy perceptions rather than objective ability motivate individuals to demonstrate entrepreneurial behaviour. However, in Kosovo, this is not the case. The large differences between the high self-perception of the knowledge, skills, and experience of students and their entrepreneurial intentions suggest that the Kosovan students have a very positive self-perception of their ability (Krasniqi, Pula, and Lajqi 2018)

Furthermore, the Iст Sector Study (PricewaterhouseCoopers 2018) reports a low rate of the quality of schools and training for people working in the digital tech sector in Kosovo, i.e. $29 \%$ extremely unhelpful, 29\% unhelpful, 14\% neutral, 29\% good conditions and $0 \%$ great conditions. On the other hand, the use of English language by Kosovan people not only indicates a sign of prestige and necessity for people who want to get educated or work abroad, but is also the main tool of communication between people inside and outside Kosovo. Graduates' proficiency in English language is keenly sought after by employers to help drive their organizations to compete successfully in the era of globalization and competitiveness (Hamid, Islam, and Hazilah 2014). Work placement modules align closely with Kolb's (1984) notion that, 'Learning is the process whereby knowledge is created through the transformation of experience'. According to Phipps and Gonzales (2004), in order to become employed, graduates should 'live' the foreign language rather than just 'have' it. They offer a concept of 'languaging' as opposed to 'language learning'. In their words, this is the process of becoming 'active agents in creating their human environment' (Phipps and Gonzalez 2004, 2). Graduates should not only be contented with learning to speak a language well but should remember that their main aim is to improve their communicative competence and abilities (Dornyei 2005; Fallah 2014).

Employability skills play a significant role in whether a candidate is hired by the desired company because these attributes are highly sought after by employers (Lowden et al. 2011). Most employers and fresh graduates agree that more emphasis should be given to the development of a student's skills and attributes, including communication, team-working, problem-solving skills, critical thinking, and leadership, otherwise known as employability skills (Lowden et al. 2011). Among these attributes, communication skills with good proficiency in English are also found to play an important role in embracing industry (Chin 2018). A similar survey was conducted in the UK where Harvey et al. (1997) reviewed these factors and concluded 
that graduates not gaining employment during the first six months were due to poor communication skills. This was further supported by Mason, Williams, and Cranmer (2006) in that the conception of employability greatly depended on the development of communication. A report generated by the Confederation of British Industry (CBI 2007) found that, among eight skills, communication and literacy were required for employability. According to the CBI, this shows how important it is for graduates to possess communication skills, which act as key factors for employability. The Harvard Business Review (McCormick 2013) informed that recruitment and HR managers around the world and applicants with exceptional English language skills (compared to the average level in their country/territory) earn 30-50\% higher salaries. Research shows a direct correlation between English language skills and economic performance. This is a virtuous cycle, with improving English skills driving up salaries, which in turn creates more money to invest in further language training.

When speaking about what foreign languages contribute for employability, it can be said that English is and continues to be, the dominant language of global trade (European Commission 2011b and CILT 2006). Lack of English language skills has been considered a barrier to accomplishing entry into employment and workforce. English communication skills are an important prerequisite for a career at a national or international level. A good command of the English language is believed to assist graduates to have better communication as they are able to deal with various challenges (Zhang et al. 2012). Being proficient in English is positively associated with being employed only for the 25-40 age group and knowing German has a positive association with employment status for the 41-64 age group (European Commission 2011a). Even though the advantage of knowing English is clear, different languages are associated with distinct employment levels in different countries. English, French, German, Russian and Spanish are the most taught languages (among languages spoken in two or more countries) in Europe, and are therefore those that Eurostat suggests should be prioritized in the identification of the best-known languages. A study conducted by Mulkerne and Graham in 2011 shows the direct relation between employability and graduates who have developed linguistic and intercultural skills. The authors show that on the labour market there is a constant demand for foreign language skills. Accordingly, languages are tools for communication, the carriers of entire worldviews, and the repositories of culture and identity. 


\section{Foreign Languages Generate Effective Communication \\ LANGUAGE SKILLS GENERATE CROSS-CULTURAL \\ COMMUNICATION}

Welch and Welch (2008) have described that language is an important aspect of culture. It is always inherent in a certain culture. If language influences the way we behave and how we perceive things, it means that culture is also inherent in the language itself. Learning a foreign language enables new working opportunities to be opened or the development of a new professional activity. Scientists identify negotiation as one of the key skill areas for working effectively across cultures. International negotiators require additional skills and competencies on top of those required in domestic business negotiations (CILт 2006). It is argued that language has a dual function, both as a means of communication and a carrier of culture. Language without culture is unthinkable, as is human culture without language. A particular language is a mirror of a particular culture. Language is what people use to express, create and interpret meanings and to establish and maintain social and interpersonal relationships. This understanding of language views language not simply as a kind of knowledge to be learnt, but as a social practice in which to participate.

Kitishat, Al Kayed, and Allah (2015) stress the importance of cultural awareness for any learner; an effective foreign language must be accompanied by cultural teaching. They argue that if students learn the language without the culture in which it is rooted, their learning will be passive because they will learn signs that are linked with the wrong signifier. Second language teachers should be second culture teachers, with the ability to experience and analyse both the home and target cultures. Teachers of the culture of a linguistic community need to know the culture to be taught and know the culture of the language learners $(\mathrm{Qu}$ 2010). Furthermore, intercultural problems arising from the use of гт have been identified relatively recently. A number of studies suggest ways in which program interface designers might develop their products for optimal use by people from different cultures (cILT 2006). In 2012, the Expert Group on Future Skills Needs (EGFSN) published a report on the skills required to trade internationally both in existing and emerging export markets. Among the skills required are foreign languages and cultural awareness. The National Employer Survey (Higher Education $\mathrm{Au}-$ thority, solAs, and Quality and Qualifications Ireland 2015) showed that approximately one quarter of employers indicated that they had 
a specific requirement for foreign language proficiency skills in their organization. The Ireland's National Skills Strategy 2025 (Department of Education and Skills 2016) lists foreign languages and cultural awareness among the cross-sectorial skills that improve an individual's employability and enable occupational mobility. Learning a foreign language is no longer a luxury for some but a necessity for most. It is an international key which upon turning will open many doors and opportunities for those that embrace and enjoy the challenge.

\section{LANGUAGE SKILLS GENERATE BUSINESS COMMUNICATION}

Foreign languages play an important role in business communication. Competence in foreign languages in business assists understanding of conversations, communication and negotiations between practitioners and foreign customers. Practitioners can run business more smoothly with the use of foreign languages (Rasouli, Dyke, and Mantler 2008) and their foreign customers will feel more comfortable. Foreign language plays a role in assisting customers who face problems in communication (Cotton, Falvey, and Kent 2007), especially in terms of communication with multinational companies and companies outside a country. Effective communication in the workplace can increase the overall productivity of a company, 'Twenty-first century organizations increasingly depend on information-sharing and effective communication to successfully run their companies' (Washington 2014, 266).

The ELAN (CILT 2006) study reports on the specific reasons given by firms to explain potential losses they have experienced. The main reasons given are lack of staff speaking languages, followed by lack of follow-up and lack of confidence. Then there are switchboard problems and difficulties with agents or distributors. Lack of cultural affinity is also cited, but by fewer companies. The studies show that the foreign language proficiency is a basic requirement in most business contexts in the workplace, and that English as the main language of global communication still holds a dominant position (e.g. Ehrenreich 2010; Kassim and Ali 2010). Graddol (2006) has charted the linguistic dimension of globalization and its implications in particular for English. As the balance of economic power shifts away from domination by the West, with the rise of the so-called BRICS (Brazil, Russia, India and China) economies the relative status and power of global languages such as Chinese, Hindi/Urdu, Portuguese and Russian will increase, according to Graddol (2006). This process will be assisted by demographics, and the technological 'catching up' of other countries with the Internet revolution in which English had 
a head start. If the language is broken down into specific situations and skills, there will be a demand for: English for negotiations (6\%) and English for meetings (5\%), German for negotiations (4\%) and correspondence (4\%), followed by English for exhibitions (4\%) and for correspondence (3\%) (CILT 2006).

\section{LANGUAGE SKILLS GENERATE KNOWLEDGE SHARING}

Language is the most basic tool of communication between humans, and it has been used for knowledge dissemination throughout the history of mankind. In its simplest form, language enables knowledge sharing through the exchange of written material such as documents, and, in its most complex form, it allows knowledge sharing through knowledge creation and sense-making by providing a framework for discussion, dialogue, and contextualization (Renzl 2007). Knowledge of a language means not only knowing its linguistic forms but also knowing how to use it (Toit 2003). Lin and Lee $(2006,75)$ have described knowledge sharing as 'the activities of how to help communities of people work together, facilitating the exchange of their knowledge and increasing their ability to achieve individual and organizational goals'. Since language is a means of knowledge sharing, any variances, discrepancies, and limitations in participants' language proficiency are likely to have considerable impact on the quality of knowledge sharing (Koskinen, Pihlanto and Vanharanta 2003). Piekkari, Welch, and Welch (1999) found that employees proficient in the corporate language were able to participate in knowledge-intensive activities such as training and seminars, and were able to network with experts from other language communities. According to Dhir and Gòkè-Paríolá (2002), transmission of information takes place through social interaction with others and thus language is a primary source that facilitates the provision of such medium for communication. The significant role of language in the knowledge sharing process is described by Husted and Michaiova (2002) as the importance of language becomes even more vital when difference in the native languages of the partner or employees increases the ambiguity substantially. The lack of fluency in the corporate language may create a possibly major obstacle even in well-codified knowledge, to being accessible and also affects the behavioural transparency which reduces the limits of understanding of each other behaviours. It leads to misunderstandings and communication problems in multicultural settings and affects the knowledge sharing, transfer and learning processes heavily. In the process of building trust (as cited in Welch and Welch 2008, 350), 'language 
becomes one of the keys that unlocks the potential contribution of trust. It is very difficult to establish a trusting relationship without an adequate basis of communication'. From the point of view of knowledge sharing and communication language dissimilarities can cause uneven patterns of interaction and knowledge sharing. In contrast to the belief that diversity in groups is seen as beneficial, language differences can have a negative impact on interaction and knowledge sharing when the group members have inadequate language skills (Mäkelä, Kalla, and Piekkari 2007).

\section{LANGUAGE SKILLS GENERATE CAREER SUCCESS}

A high level of knowledge of a foreign language enables one to do things that would otherwise be impossible. 'Business is always and in any context looking for the language skill in conjunction with some other skill or expertise' (Wabenhorst 1992). The combination of a foreign language and another skill is a major selling point for the job-hunter. Employability skills comprise specific personal characters and skills that enhance the employment prospects of a graduate. Therefore, employability skills are beneficial not just to the graduate, but also to the organization in which the graduate works (Tejan and Sabil 2006). To a greater extent, education is considered to be the vehicle of the creation and growth of new entrepreneurial and technological ideas which form the basis for innovation and growth. Indeed, the universities play a significant role in enhancing the absorptive capacity of actors such as employees at firms and researchers at universities and research institution need to drive the economic growth (Audretsch, Lehmann, and Wright 2014). Accordingly, Clarke (2018) holds the view that employability skills is not just the responsibility of the graduate alone, but that employers and universities should also help graduates in developing the desirable employability skills. Ali, Othman, and Ahmad (2017) in their study reported that employers are focusing a lot of attention on graduate skills and this calls for universities to also focus more on equipping their graduates with skills that are needed in the job market. The latter will help in increasing the graduates' chances of gaining employment as they will have the necessary skills to adapt to the changing business environment.

International mergers and acquisitions that constantly shape business have shifted focus from solely professional skills towards requirements regarding language capabilities (Piekkari 2008). Globalization and cultural issues have wide effects on careers in today's organizations (Bloch 1995; Leong and Hartung 2000, 212). Entirely 
new job positions are created and new skills and qualifications are required (Buchholz, Hofäcker, and Blossfeld 2006). Integrating foreign language skills with business skills, educational background and cross-cultural communication skills is essential (Bloch 1995) Furthermore, language skills can secure one's position in the field of international business, and offer capabilities to perform international tasks well and effectively (Bloch 1995).

\section{Discussion and Conclusion}

The changing global economy and international settings demand high levels of foreign language skills, as well as cultural competencies to be taken into account both for employees and graduates and while conducting business. In this respect, we support the idea that increased foreign language knowledge unavoidably leads to employability and up-to-date labour market knowledge. The role of university language departments is crucial, both with regard to developing expertise in modern languages as well as in teaching foreign languages.

In the future, the need for language skills is most likely to increase in Kosovo and beyond. Occupational standards should serve as a letter of guarantee for qualifications earned by individuals in different fields. Such standards which should be developed in line with the European Qualifications Standard, aim to prove that an individual who has earned an occupational standard is fully competent in performing a given task/role in the organization. The process for the development of such standards needs to be accelerated in the future (Hapçiu and Osmani 2018). The labour legislation in Kosovo should be amended with a view to creating a more dynamic labour market that encourages competition and labour force productivity. Additionally, institutions should work to remove all potential barriers. Kosovo should also work towards empowering social dialogue as a very important link to ensuring the harmonization of education and labour policies (Hapçiu and Osmani 2018). The Stabilization and Association Agreement between Kosovo and European Union Article 107 Education and Training (p. 15) says that they shall cooperate with the aim of raising the level of general education and vocational education and training as well as youth policy and youth work in Kosovo, as a means to promote skills development, employability, social inclusion and economic development in Kosovo. The relevant $\mathrm{E} \mathrm{U}$ programmes and instruments shall contribute to the upgrading of educational, training, research and innovation structures and activities in Kosovo. 
Education is considered to be the vehicle to the creation and growth of new entrepreneurial and technological ideas which form the basis for innovation and growth. Indeed, the universities play a significant role in enhancing the absorptive capacity of actors such as employees at firms and researchers at universities and research institution need to drive the economic growth (Audretsch, Lehmann and Wright 2014). There is a critical need to ensure that all students across all disciplines have an opportunity for entrepreneurial learning (European Commission 2008). Not only the promotion of entrepreneurship in tertiary education, but the promotion of entrepreneurial learning at secondary and vocational education is very important for developing an entrepreneurial culture. Entrepreneurship education incorporates the courses, programmes and processes offered to students to strengthen their entrepreneurial traits, attitudes, skills and knowledge required for starting and growing new ventures (Hahn et al. 2017). Ways should be found to provide language training for employees, provide work experience opportunities for foreign students and employees, make use of migrant workers' language skills and to seek opportunities to collaborate with educational institutions in order to support language education and training.

It can be concluded that if individuals want to remain employable and graduates are to meet labour market demands, they should embrace multilingualism. Despite the fact that English is the most studied language in the world, in many European and global companies, languages other than English are used. Hence, the contribution of foreign languages to employability, competitiveness and achievement is too obvious to be doubted.

Our research was limited to the effects of foreign languages on employment, communication, intercultural competence and career success. Future research could focus on economic, social and political dimensions, on democracy and diversity. Finally, our recommendation to graduates is to review the language needs in particular markets while educational institutions should also be aware of the importance of their role as support service providers in the area of language training.

\section{References}

Ali, F. M. A., R. Othman, and B. Ahmad. 2017. 'Graduate's Marketable Skills: An Empirical Investigation of its Effect on Perceived Marketability of Yemeni Graduates in the Arab Gulf States.' International Journey of Education \& Literacy Studies 7 (2): 134-38. 
Audretsch, D. B., E. E. Lehmann, and M. Wright. 2014. 'Technology Transfer in a Global Economy.' The Journal of Technology Transfer 39 (3): 301-12.

Bandura, A. 1997. Self-Efficacy: The Exercise of Control. New York: Worth.

Bloch, B. 1995. 'Career Enhancement through Foreign Language Skills.' The International Journal of Career Management 7 (6): 15-26.

Buchholz, S., D. Hofäcker and H.-P. Blossfeld. 2006. 'Globalization, Accelerating Economic Change and Late Careers: A Theoretical Framework.' In Globalization, Uncertainty and Late Careers in Society, edited by H.-P. Blossfeld, S. Buchholz, and D. Hofäcker, 1-24. Oxford: Routledge.

Confederation of British Industry. 2007. Employment Trends 2009: Work Patterns in the Recession. London: Confederation of British Industry.

Chin, C. 2018. 'Varsity Aims to Boost Grads' Employability.' The Star Online, 4 March. https://www.thestar.com.my/news/nation/2018/03/o4 /varsity-aims-to-boost-grads-employability.

cilt, the National Center for Languages. 2006. 'Effects on the European Union Economy of Shortages of Foreign Language Skills in Enterprise (ELAN).' https://ec.europa.eu/assets/eac/languages/policy/ strategic-framework/documents/elan_en.pdf.

Clarke, M. 2018. 'Rethinking Graduate Employability: The Role of Capital, Individual Attributes and Context.' Studies in Higher Education 43 (11): 1923-37.

Cojocaru, A. 2017. Kosovo Jobs Diagnostic Report. Jobs Series 5. Washington, DC: The World Bank.

Cotton, D., D. Falvey, and S. Kent. 2007. 'The Keys to Successful Team Building.' Market Leader 71:16o.

Department of Education and Skills. 2016. Ireland's National Skills Strategy 2025. Dublin: Department of Education and Skills.

Dhir, K. S., and A. Gòkè-Paríolá. 2002. 'The Case for Language Policies in Multinational Corporations.' Corporate Communications: An International Journal 7 (4): 241-51.

Dornyei, Z. 2005. 'The Internal Structure of Language Learning Motivation: Results of Structural Equation Modelling.' Modern Language Journal 89 (1): 19-36.

Expert Group of Future Skills Need. 2012. Key Skills for Enterprise to Trade Internationally. Dublin: Expert Group of Future Skills Need.

Ehrenreich, S. 2010. 'English as a Business Lingua Franca in a German Multinational Corporation: Meeting the Challenge.' Journal of Business Communication 47 (4): 408-31.

European Commission. 2008. 'Entrepreneurship in Higher Education, Especially Within Non-business Studies.' Final Report of the Expert Group, European Commission, Brussels.

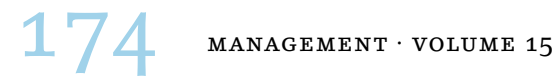


2011a. 'Languages for Jobs: Providing Multilingual Communication Skills for the Labour Market.' Report from the Thematic Working Group 'Languages for Jobs', European Commission, Brussels.

- 2011b. 'Report on Language Management Strategies and Best Practice in European smes: The PImLico Project.' European Commission, Brussels.

Fallah, N. 2014. 'Willingness to Communicate in English, Communication Self-confidence, Motivation, Shyness and Teacher Immediacy among Iranian English-major Undergraduates: A Structural Equation Modelling Approach.' Learning and Individual Differences 30:140-47.

Gallagher-Brett, A. 2004. Seven Hundred Reasons for Studying Languages. Southampton: Subject Centre for Languages, Linguistics and Area Studies.

Graddol, D. 2006. English Next. London: British Council.

Hahn, D., T. Minola, A. Van Gils, and J. Huybrechts, 2017. 'Entrepreneurial Education and Learning at Universities: Exploring Multilevel Contingencies.' Entrepreneurship \& Regional Development 29 (9-10): 945-74.

Hamid, A., R. Islam, and N. Hazilah. 2014. 'Malaysian Graduates' Employability Skills Enhancement: An Application of the Importance Performance Analysis.' Journal of Global Business Advancement 7 (3): 181-97.

Hapçiu, V., and V. Osmani. 2018. Education and Labor Market in Kosovo and $\mathrm{EU}$. Prishtina: American Chamber of Commerce in Kosovo.

Harvey, L., S. Moon, V. Geall, and R. Bower. 1997. Graduates' Work: Organisation Change and Students' Attributes. Birmingham, AL: Centre for Research into Quality and Association of Graduate Recruiters.

Higher Education Authority, solAs, and Quality and Qualifications Ireland. 2015. National Employer Survey: Employers' Views on Irish Further and Higher Education and Training Outcomes. Dublin: Higher Education Authority, solas and Quality and Qualifications Ireland.

Husted, K., and S. Michaiova. 2002. 'Knowledge Sharing in Russian Companies with Western Participation.' Management International 6 (2): 17-28.

Kassim, H., and F. Ali. 2010. 'English Communicative Events and Skills Needed at the Workplace: Feedback from the Industry.' English for Specific Purposes 29 (3): 168-82.

Kita, L. 2008. HRD Country Analyses for Western Balkan Countries: Kosovo. Turin: European Training Foundation.

Kitishat, A., M. Al Kayed, and H. F. Allah. 2015. 'Second Language Learning and the Cultural Knowledge, the Inseparable Process: A Case Study of Studying English at Jordanian Universities.' Journal of Literature, Languages and Linguistics 11:88-96. 
Kolb, D. A. 1984. Experiential Learning: Experience as the Source of Learning and Development. Englewood Cliffs, nJ: Prentice-Hall.

Koskinen, K. U., P. Pihlanto, and H. Vanharanta, 2003. 'Tacit Knowledge Acquisition and Sharing in a Project Work Context.' International Journal of Project Management 21 (4): 281-90.

Kosovo Agency of Statistics. 2013. Kosovo in Figures 2013. Prishtina: Kosovo Agency of Statistics.

Krasniqi, A. B., J. Sh. Pula, and S. Lajqi. 2018. 'Entrepreneurial Education and Career Choice in Kosovo.' Paper presented at the International Conference 'Education, Labor Market and economic Development', Academy of Sciences and Arts of Kosovo, Prishtina, 26 October 26.

Leitch, C., S.-A. Hazlett, and L. Pittaway. 2012. 'Entrepreneurship Education and Context.' Entrepreneurship \& Regional Development 24 (9-10): 733-40.

Leong, F. T. L., and P. J. Hartung. 20oo. 'Adapting to the Changing Multicultural Context of Career.' In The Future of Career, edited by A. Collin and R. A. Young, 212-27. Cambridge: Cambridge University Press.

Lin, H. F., and G. G. Lee. 2006. 'Effects of Socio-technical Factors on Organizational Intention to Encourage Knowledge Sharing.' Management Decision 44 (1): 74-88.

Lowden, K., S. Hall, D. Elliot, and J. Lewin. 2011. Employers' Perceptions of the Employability Skills of New Graduates. London: Edge Foundation.

Mäkelä, K., H. K. Kalla, and R. Piekkari. 2007. 'Interpersonal Similarity as Driver of Knowledge Sharing Within Multinational Corporations.' International Business Review 16 (1): 1-22.

Markman, G. D., D. B. Balkin, and R. A. Baron. 2002. 'Inventors and New Venture Formation: The Effects of General Self-efficacy and Regretful Thinking.' Entrepreneurship Theory and Practice 27 (2): 149-65.

Martin, B. C., J. J. McNally, and M. J. Kay. 2013. 'Examining the Formation of Human Capital in Entrepreneurship: A Meta-Analysis of Entrepreneurship Education Outcomes.' Journal of Business Venturing 28 (2): 211-24.

Mason, G., G. Williams, and S. Cranmer. 2006. Employability Skills Initiatives in Higher Education: What Effects Do They Have on Graduate Labour Outcomes? London: National Institute of Economic and Social Research.

McCormick, C. 2013. 'Countries with Better English have Better Economies.' Harvard Business Review, 15 November. https://hbr.org/2013 /11/countries-with-better-english-have-better-economies.

Ministry of Labour and Social Welfare. 2010. 'Vocational Training Strategy 2012-2014.' Ministry of Labour and Social Welfare, Prishtina. 
Mulkerne, S., and A-M. Graham. 2011. Labor Market Intelligence on Languages and Intercultural Skills in Higher Education. Southampton: University Council of Modern Languages.

Phipps, A., and M. Gonzalez. 2004. Modern Languages: Learning and Teaching in an Intercultural Field. London: Sage.

Pichl, E. 1999. The State of Higher Education in Kosovo. Graz: wus Austria \& Institute of Austrian, European and Comparative Public.

Piekkari, R., D. Welch, and L. Welch. 1999. 'Adopting a Common Corporate Language: IHRM Implications.' International Journal of Human Resource Management 10 (3): 377-90.

Piekkari, R. 2008. 'Languages and Careers in Multinational Corporations.' In International Management and Language, edited by S. Tietze, 128-137. London: Routledge.

Polloshka, B. 2018. Fifth Annual Conference of the International Association of Language Commissioners 'Multilingualism: Value and/or Obligation'. https://languagecommissioners.org/userfiles/files/5th _IALC_Conference_report_-_Multilingualism_May_04_2018.pdf.

PricewaterhouseCoopers. 2018. 'Іст Sector Study: Macedonia, Albania, Kosovo.' https://masit.org.mk/wp-content/uploads/2018/o1/ 20180704-pwcictsectorstudy_draftmak-2.pdf.

Qu, Y. 2010. 'Culture Understanding in Foreign Language Teaching.' English Language Teaching 3 (4): 58-61.

Rasouli, M., L. Dyke, and J. Mantler, 2008. 'The Role of Language and Career Management Self-efficacy on the Career Adjustment of Immigrant Women in Canada.' The International Journal of Diversity in Organizations, Communities and Nations 8 (5): 33-42.

Renzl, B. 2007. 'Language as a Vehicle of Knowing.' Knowledge Management Research \& Practice 5 (1): 44-53.

Rrumbullaku, O. 2019. Youth Study Kosovo 2018-2019. Berlin: The Friedrich-Ebert-Stiftung.

Skills 2020 Kosovo. 2014. Turin: European Training Foundation.

The World Bank. 2012. Kosovo: Gender Gaps in Education, Health and Economic Opportunities. Washington, Dc: The World Bank.

- 2019. Kosovo Country Report: Findings from the Skills towards Employment and Productivity Survey. Washington, Dc: The World Bank.

Tejan, O. A., and A. Sabil. 2006. 'Understanding Employers' Perception of Employability Skills and Career Development in Morocco.' International Journal of Education and Literacy Studies 7 (2): 134-38.

Toit, A. 2003. 'Knowledge: A Sense-making Process Shared Through Narrative.' Journal of Knowledge Management 7 (3): 27-37.

Wabenhorst, H. P. 1992. 'The Potential and the Importance of the German Language for Australian Business.' Paper presented on the occasion of the Modern Language Teacher's Association of Victoria congress, German program, Melbourne, 26 May.

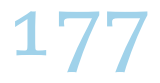


Washington, M. C. 2014. 'The Impact of Writing Assignments in Business Education: Toward a Competitive Advantage in the Workplace.' American Journal of Business Education 7 (3): 265-70.

Welch, D. E., and L. S. Welch. 2008. 'The Importance of Language in International Knowledge Transfer.' Management International Review 48 (3): 339-6o.

Zhang, W., S. Hong, D. T. Takeuchi, and D. T. Mossakowski. 2012. 'Limited English Proficiency and Psychological Distress among Latinos and Asian Americans.' Social Science \& Medicine 75 (2): 1006-14. 